\title{
Nitrogen rates on the agronomic performance of second-crop corn single and intercropped with ruzigrass or showy rattlebox ${ }^{1}$
}

\author{
Moryb Jorge Lima da Costa Sapucay ${ }^{2}$, Antonio Eduardo Coelho ${ }^{3}$, Felipe Bratti ${ }^{4}$, \\ Jorge Luiz Locatelli ${ }^{5}$, Luis Sangoi ${ }^{3}$, Alvadi Antonio Balbinot Junior ${ }^{6}$, Claudemir Zucareli ${ }^{2}$
}

ABSTRACT

Topdressing nitrogen $(\mathrm{N})$ rates may alter the second-crop corn performance, and this response may vary if the corn is grown single or intercropped with grass or leguminous species. This study aimed to evaluate the effect of topdressing $\mathrm{N}$ rates on the growth and productive performance of second-crop corn grown single or intercropped with ruzigrass (Urochloa ruziziensis) or showy rattlebox (Crotalaria spectabilis). The experiment was carried out in a randomized block design, with a split-plot arrangement and four replications. The plots consisted of corn grown single or intercropped with ruzigrass or showy rattlebox, while the subplots consisted of $\mathrm{N}$ rates $(0$, $60,120,180$ and $\left.240 \mathrm{~kg} \mathrm{ha}^{-1}\right)$. The evaluated variables were: SPAD index at R1; normalized difference vegetation index at V4 and V7; leaf area at R1; leaf and total corn dry mass at R1; grain and total corn dry mass at R6; number of ears per plant and grains per ear; 1,000-grain mass; and grain yield. In the absence of $\mathrm{N}$ fertilization and with topdressing of $60 \mathrm{~kg} \mathrm{ha}^{-1}$ of $\mathrm{N}$, the intercropping with $U$. ruziziensis reduces the growth and productive performance of second-crop corn. The topdressing $\mathrm{N}$ fertilization for second-crop corn intercropped with U. ruziziensis minimizes the forage competition on corn growth and provides a productive performance similar to monocropping from $120 \mathrm{~kg} \mathrm{ha}^{-1}$ of $\mathrm{N}$. The intercropping with C. spectabilis does not change the corn growth and productive performance, as well as the response to the topdressing $\mathrm{N}$ rates, when compared to monocropping, in the second crop cultivation.

KEYWORDS: Zea mays L., Urochloa ruziziensis, Crotalaria spectabilis, nitrogen fertilization.

\section{INTRODUCTION}

In Brazil, second-crop corn is sown after the summer crop (mostly soybean), from January to

\section{RESUMO}

Doses de nitrogênio no desempenho agronômico de milho segunda safra solteiro e consorciado com braquiária ou crotalária

Doses de nitrogênio $(\mathrm{N})$ em cobertura podem alterar o desempenho da cultura do milho segunda safra, e essa resposta pode variar se o milho for cultivado solteiro ou consorciado com espécies de gramíneas ou leguminosas. Objetivou-se avaliar o efeito de doses de $\mathrm{N}$ aplicadas em cobertura no crescimento e desempenho produtivo de milho segunda safra solteiro e consorciado com braquiária (Urochloa ruziziensis) ou crotalária (Crotalaria spectabilis). O delineamento experimental foi em blocos casualizados, com parcelas subdivididas e quatro repetições. As parcelas foram constituídas pelo milho solteiro, consorciado com braquiária ou com crotalária, e as subparcelas pelas doses de $\mathrm{N}\left(0,60,120,180\right.$ e $\left.240 \mathrm{~kg} \mathrm{ha}^{-1}\right)$. As variáveis avaliadas foram: índice SPAD em R1; índice de vegetação por diferença normalizada em V4 e V7; área foliar em R1; massa seca de folha e total do milho em R1; massa seca de grão e total do milho em R6; número de espigas por planta e de grãos por espiga; massa de mil grãos; e produtividade de grãos. Na ausência de adubação nitrogenada e com uso de $60 \mathrm{~kg} \mathrm{ha}^{-1}$ de $\mathrm{N}$ em cobertura, o consórcio com U. ruziziensis reduz o crescimento e o desempenho produtivo de milho segunda safra. A adubação nitrogenada de cobertura no milho segunda safra em consórcio com U. ruziziensis minimiza a competição da forrageira sobre o crescimento do milho e proporciona, a partir de $120 \mathrm{~kg} \mathrm{ha}^{-1} \mathrm{de}$ $\mathrm{N}$, desempenho produtivo similar ao do cereal solteiro. O consórcio com C. spectabilis não altera o crescimento e o desempenho produtivo do milho, bem como a resposta a doses de $\mathrm{N}$ aplicadas em cobertura, em relação ao milho solteiro, na segunda safra.

PALAVRAS-CHAVE: Zea mays L., Urochloa ruziziensis, Crotalaria spectabilis, adubação nitrogenada.

April. Its cultivated area, production and national yield has increased in the last decades, evidencing the consolidation of the soybean/corn succession under no-tillage (Conab 2020).

${ }^{1}$ Received: Sep. 11, 2020. Accepted: Nov. 27, 2020. Published: Dec. 08, 2020. DOI: 10.1590/1983-40632020v5065525.

${ }^{2}$ Universidade Estadual de Londrina, Centro de Ciências Agrárias, Departamento de Agronomia, Londrina, PR, Brasil.

Email/ORCID: moryb_sapucay@hotmail.com/0000-0001-8094-3647, claudemircca@uel.br/0000-0002-5260-0468.

${ }^{3}$ Universidade do Estado de Santa Catarina, Lages, SC, Brasil.Email/ORCID: coelhoagro7@gmail.com/0000-0002-3991-9343, luis.sangoi@udesc.br/0000-0002-9102-4248.

${ }^{4}$ Universidade Federal do Paraná, Curitiba, PR, Brasil. Email/ORCID: felipe-bratti@hotmail.com/0000-0002-8179-7183.

${ }^{5}$ Universidade de São Paulo, Escola Superior de Agricultura Luiz de Queiroz, Piracicaba, SP, Brasil.

Email/ORCID: jorgellocatelli@gmail.com/0000-0002-2545-8259.

${ }^{6}$ Empresa Brasileira de Pesquisa Agropecuária (Embrapa Soja), Londrina, PR, Brasil.

Email/ORCID: alvadi.balbinot@embrapa.br/0000-0003-3463-8152. 
Solar radiation, temperature and water availability are less favorable to corn growth and yield during the second crop cultivation (Maldaner et al. 2014), requiring the use of management techniques that provide a maximum yield with the rationalization of production costs.

The inadequate nitrogen $(\mathrm{N})$ supply is a limiting factor to corn grain yield, because it is the nutrient most absorbed by this crop, providing a high growth and productive response, as long as other factors are not limiting (Al-Naggar et al. 2015). However, some producers have chosen to use lower $\mathrm{N}$ rates or its total suppression during the second-crop corn, because the weather conditions of that period are more restrictive, limiting the crop response to the nutrient. In addition, second-crop corn, in general, is preceded by soybean, a legume that releases $\mathrm{N}$ to the soil. However, studies have shown that the topdressing $\mathrm{N}$ application to corn positively influences its productive performance in the second crop cultivation, even when it is grown in succession to soybean (Kappes et al. 2009, Raasch et al. 2016).

The interest in cultivating second-crop corn intercropped with ruzigrass or showy rattlebox under no-tillage has been growing (Kappes \& Zancanaro 2015). Tropical forages, especially those of the Urochloa genus, provide a high straw production and nutrient cycling, factors that contribute to the no-tillage sustainability (Franchini et al. 2014). Moreover, the root system improves the soil physical quality (Chioderoli et al. 2012), providing a higher yield to the soybean crop in succession (Balbinot Junior et al. 2017).

In turn, corn intercropped with showy rattlebox can increase the amount of straw, amount of $\mathrm{N}$ in the soil, nutrient cycling and control of nematodes that attack the soybean crop (Gitti et al. 2012, Souza et al. 2019). As a leguminous species, showy rattlebox promotes atmospheric $\mathrm{N}$ fixation, probably not competing for soil mineral $\mathrm{N}$ with corn.

Therefore, second-crop corn intercropped with ruzigrass or showy rattlebox may benefit the production system. However, the intercropped cultivation may increase the interspecific competition for water, light and nutrients, especially N, mainly under the specific climate conditions of the second crop cultivation, when precipitation is scarce (Kappes \& Zancanaro 2015). Thus, it is necessary to adapt topdressing $\mathrm{N}$ rates to meet the requirements of corn subjected to intercropped systems, considering the morphophysiological characteristics of the used cover species.

In this context, this research hypothesized that an increase in topdressing $\mathrm{N}$ rates may minimize the competition of ruzigrass plants intercropped with second-crop corn, while the responses of corn intercropped with showy rattlebox to $\mathrm{N}$ rates are similar to those of monocropping. Thus, this study aimed to evaluate the effect of topdressing $\mathrm{N}$ rates on the growth and productive performance of secondcrop corn grown single or intercropped with ruzigrass (Urochloa ruziziensis) or showy rattlebox (Crotalaria spectabilis).

\section{MATERIAL AND METHODS}

The experiment was carried out in Londrina, Paraná state, Brazil $\left(23^{\circ} 11^{\prime} \mathrm{S}, 51^{\circ} 11^{\prime} \mathrm{W}\right.$ and altitude of $620 \mathrm{~m}$ ), during the second-crop cultivation of 2018 and 2019, at the same experimental area. The soil of this area is classified as Latossolo Vermelho Distroférrico (Santos et al. 2018) or Rhodic Eutrudox (USDA 2014), with a particle size distribution consisting of 710, 82 and $208 \mathrm{~g} \mathrm{~kg}^{-1}$ of clay, silt and sand, respectively, managed under no-tillage for 10 years. Soil samples were collected at a depth of 0-20 cm, before the experiment was set up, to perform the chemical analysis, which presented the following results: $\mathrm{pH}\left(\mathrm{CaCl}_{2}\right)$ : 5.09; $\mathrm{P}: 13.89 \mathrm{mg} \mathrm{dm}^{-3}$ (Mehlich 1); organic matter: $28.86 \mathrm{~g} \mathrm{~kg}^{-1}$ (Walkley Black); Al: $0.0 \mathrm{cmol}_{\mathrm{c}} \mathrm{dm}^{-3} ; \mathrm{H}+\mathrm{Al}: 4.96 \mathrm{cmol}_{\mathrm{c}} \mathrm{dm}^{-3}$; $\mathrm{K}: 0.59 \mathrm{cmol}_{\mathrm{c}} \mathrm{dm}^{-3}$; $\mathrm{Ca}: 4.16 \mathrm{cmol}_{\mathrm{c}} \mathrm{dm}^{-3} ; \mathrm{Mg}$ : $2.05 \mathrm{cmol}_{\mathrm{c}} \mathrm{dm}^{-3}$; sum of bases: $6.80 \mathrm{cmol}_{\mathrm{c}} \mathrm{dm}^{-3}$; cation exchange capacity: $11.76 \mathrm{cmol}_{\mathrm{c}} \mathrm{dm}^{-3}$; and base saturation: $57 \%$.

The regional climate is type $\mathrm{Cfa}$, according to the Köppen classification, described as a subtropical humid mesothermal climate, with warm summers and infrequent frosts. The precipitation and temperature data during the experimental period were collected from a weather station located $500 \mathrm{~m}$ away from the experimental area and used to make the sequential climatological water balance (Thornthwaite \& Mather 1955), with an available water capacity of $75 \mathrm{~mm}$ (Figure 1).

A completely randomized block design, in a split-plot arrangement, with four replications, was used. The plots consisted of three cultivation systems [corn grown single (cv. AG 9010 PRO) 

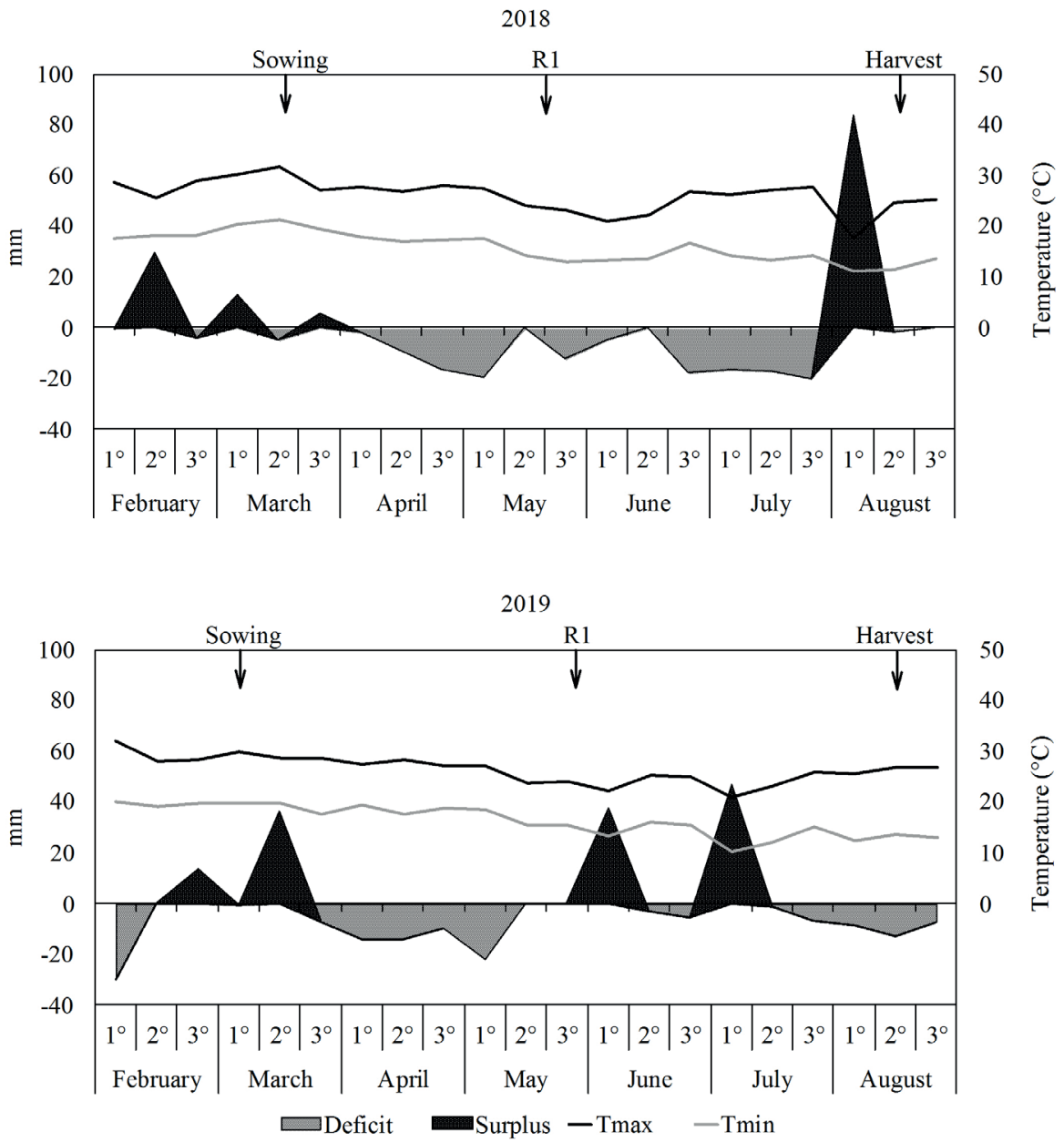

Figure 1. Sequential climatological water balance (mm), maximum (Tmax) and minimum (Tmin) temperatures, during the 2018 and 2019 growing seasons, from February 1st to August 31st, according to Thornthwaite \& Mather (1955), with a $75 \mathrm{~mm}$ available water capacity, considereing the data from the weather station located in Londrina, Paraná state, Brazil. Total precipitation from corn sowing to harvest: $301 \mathrm{~mm}$ (2018 growing season) and $380 \mathrm{~mm}$ (2019 growing season).

and intercropped with ruzigrass (U. ruziziensis) or showy rattlebox (C. spectabilis)], while the subplots consisted of topdressing $\mathrm{N}$ rates $(0,60,120,180$ and $\left.240 \mathrm{~kg} \mathrm{ha}^{-1}\right)$ as ammonium nitrate ( $33 \%$ of $\left.\mathrm{N}\right)$, with six corn rows (eight meters long) spaced at $0.85 \mathrm{~m}$, considering as useful area the four central rows without $0.5 \mathrm{~m}$ of each end.

The corn was sown on March 16, 2018 and March 6, 2019, on the soybean straw, using a seedcum-fertilizer drill with furrow-opening mechanisms to place the fertilizer and lagged double discs to place the seeds. The machine was set for a density of 65 thousand plants $\mathrm{ha}^{-1}$.

The base fertilization in the 2018 and 2019 growing seasons consisted of $310 \mathrm{~kg} \mathrm{ha}^{-1}$ of the NPK $\left(\mathrm{N}-\mathrm{P}_{2} \mathrm{O}_{5}-\mathrm{K}_{2} \mathrm{O}\right.$ ) formulation 08-28-16 and $420 \mathrm{~kg} \mathrm{ha}^{-1}$ of $08-20-20$. The ruzigrass and showy rattlebox were mechanically sown in the intercropping systems at the corn sowing time, using an additional box for small seeds and distribution through a helical grooved rotor with a single groove centered on the corn inter-rows, using 10 and $25 \mathrm{~kg} \mathrm{ha}^{-1}$ of pure and viable seeds, respectively.

The topdressing $\mathrm{N}$ fertilization was broadcasted and split into two applications $(50 \%+50 \%)$, when the plants were at V4 and V8. Also, all the treatments received $60 \mathrm{~kg} \mathrm{ha}^{-1}$ of potassium chloride $(60 \%$ of $\mathrm{K}_{2} \mathrm{O}$ ) during the second broadcast $\mathrm{N}$ application in both growing seasons. Weeds were controlled during the corn cycle by manual weeding. Pests and diseases were controlled according to the need and recommendations for the crop.

The following evaluations were carried out: a) SPAD index: obtained by the average of two 
readings in six plants on the ear leaf at R1, using a Konica Minolta ${ }^{\mathrm{TM}}$ Spad 502 chlorophyll meter. The readings were taken between 8:30 and 10:00 a.m.; b) normalized difference vegetation index (NDVI), given by the ratio: $\mathrm{NDVI}=(\mathrm{NIRR}-\mathrm{R}) /(\mathrm{NIRR}+\mathrm{R})$, where $\mathrm{R}$ refers to the reflectance in the red region $(680 \mathrm{~nm})$ and NIRR to the near-infrared reflectance (770 nm), using the Green Seeker ${ }^{\mathrm{TM}} 505$ Handheld Sensor equipment positioned on the central row of each plot to perform readings at V4 and V7; c) leaf area per plant: estimated at silking (R1) by applying the expression: $\mathrm{LA}=\mathrm{L} \times \mathrm{W} \times 0.75$, where $\mathrm{L}$ and $\mathrm{W}$ represent the average length and width, respectively, measured at the largest point of each leaf of six plants; d) leaf dry mass and total dry mass (leaf, stem, ear and tassel dry mass) at R1: three plants were randomly collected (cut at the ground level) from one of the rows of the plot's useful area, with the leaves separated from the other parts. The mass was measured on a precision scale after drying in a forced-air ventilation oven at $60^{\circ} \mathrm{C}$, for $72 \mathrm{~h}$; e) grain dry mass and total dry mass (dry mass of leaf, stem, ear without grains, straw, cob and tassel) at R6: three plants were randomly collected (cut at the ground level) from one of the rows of the plot's useful area, with the parts separated. The mass was measured on a precision scale after drying in a forced ventilation oven at $60^{\circ} \mathrm{C}$, for $72 \mathrm{~h}$.

The following evaluations were carried out at the corn harvest point ( $22 \%$ of moisture): a) number of ears per plant: determined by counting the number of ears in two rows of the subplot's useful area; b) number of grains per ear: determined by the ratio between the grain mass in the useful area and the 1,000-grain mass. Subsequently, the number of grains was divided by the number of ears in the useful area; c) 1,000-grain mass: average mass of eight replications of 100 grains per subplot, obtained on a precision scale and extrapolated to 1,000 grains; d) grain yield: manual harvesting was carried out in two rows of the subplot's useful area. The yield was determined and extrapolated to $\mathrm{kg} \mathrm{ha}^{-1}$ after threshing, processing and weighing, with an average water content of $130 \mathrm{~g} \mathrm{~kg}^{-1}$ of grains.

The data were submitted to normality and homoscedasticity analyses, indicating the fulfillment of the statistical assumptions. Subsequently, the data were submitted to analysis of variance. $A p \leq 0.25$ was considered for the interaction effect and $\mathrm{p} \leq 0.05$ for the isolated effect of factors (Perecin \& Cargnelutti
Filho 2008). The means of the variables were compared by the Tukey test in the qualitative factor (cultivation systems) and subjected to regression analysis $(\mathrm{p} \leq 0.05)$ in the quantitative factor ( $\mathrm{N}$ rates), using the Sisvar statistical software (Ferreira 2011).

\section{RESULTS AND DISCUSSION}

The precipitation rates in both growing seasons were lower than the historical average of the region: $490 \mathrm{~mm}$ during the experimental period (March to August) (Sibaldelli \& Farias 2018). Thus, the $301 \mathrm{~mm}$ observed during the corn cycle in the 2018 growing season and $380 \mathrm{~mm}$ in the 2019 growing season corresponded to precipitation deficits of 189 and $110 \mathrm{~mm}$, respectively (Figure 1).

Considering that corn requires $400-600 \mathrm{~mm}$ of water during its cycle to produce grains (Cruz et al. 2017), the water deficit in both growing seasons led to a limitation of the crop growth and development, compromising its yield. This limitation was more evident in the 2018 growing season, when the water deficit occurred after V4 until the physiological maturation (Figure 1). The shorter deficit duration in the 2019 growing season after V4 until two weeks before R1 allowed for better conditions of corn production. Likewise, the cover crops had their growth more compromised in the 2018 growing season than in the 2019 one.

The 2018 growing season presented an interaction between corn cultivation systems and topdressing $\mathrm{N}$ rates for the SPAD index at R1, leaf area at $\mathrm{R} 1$ and number of ears per plant. The isolated factors showed an effect of the intercropping on NDVI at V4. The 2019 growing season presented an interaction for leaf area, total dry mass at R6, number of grains per ear, 1,000-grain mass and grain yield. The isolated factors showed an effect of the intercropping on NDVI at V7 and grain dry mass at R6.

The SPAD index at R1 was not influenced by experimental factors in the 2019 growing season. However, the SPAD index for corn intercropped with showy rattlebox was higher than for corn intercropped with ruzigrass in the 2018 growing season, when there was no topdressing $\mathrm{N}$ fertilization, but these systems showed no difference from each other when $\mathrm{N}$ was topdressed applied (Figure 2A). In addition, no response from the SPAD index at R1 to the increase in $\mathrm{N}$ rates was observed, regardless of the cultivation system, probably because the water deficit 
limited the corn response to this nutrient. Nitrogen acts in various physiological processes of crops, so that an increase in nutrient levels is associated with a higher chlorophyll index and photosynthetic rate in the leaves, while low levels negatively affect the amount or activity of photosynthetic components (Mahama et al. 2016).
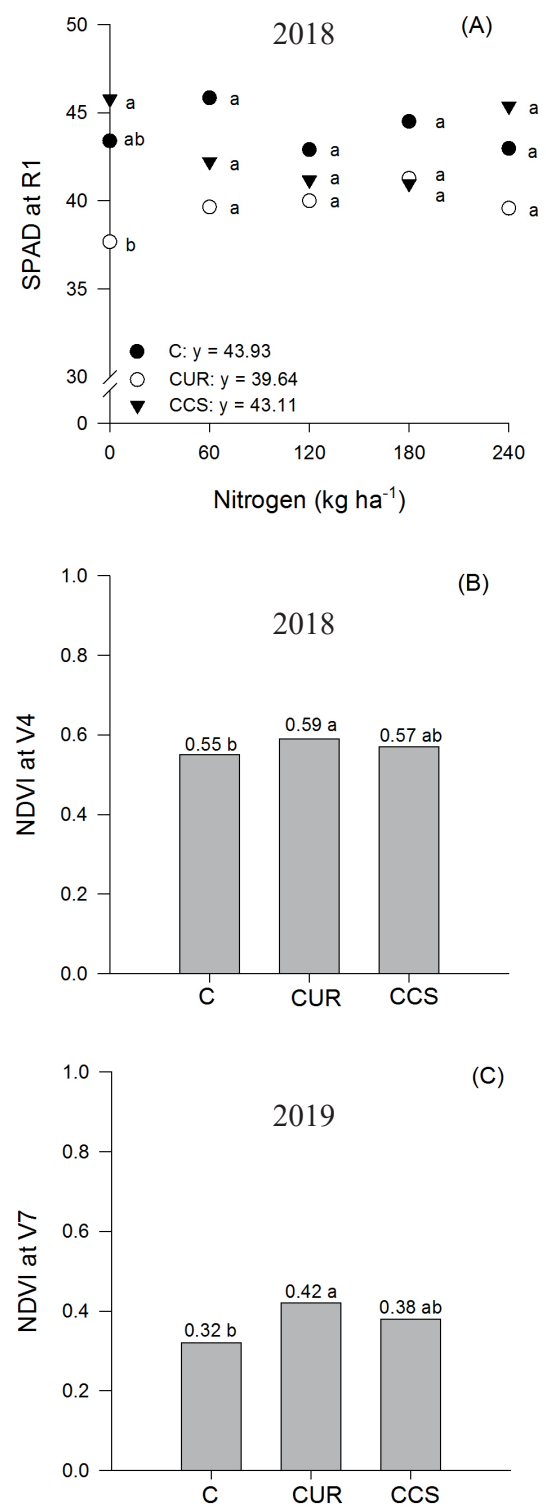

Figure 2. Effect of cultivation systems (C: corn monocropping; CUR: corn + Urochloa ruziziensis; and CCS: corn + Crotalaria spectabilis) and topdressing nitrogen rates $\left(0,60,120,180\right.$ and $\left.240 \mathrm{~kg} \mathrm{ha}^{-1}\right)$ on second-crop corn, regarding the SPAD index at $\mathrm{R} 1$ (A) and normalized difference vegetation index (NDVI) at V4 and V7 (B and C), during the second crop cultivation of 2018 and 2019. Means followed by the same letter within each nitrogen rate do not differ from each other by the Tukey test at $5 \%$ of probability.
It is likely that the higher interspecific competition caused by ruzigrass, when compared to showy rattlebox, has reduced the amount of $\mathrm{N}$ absorbed by corn under the edapho-meteorological conditions of the 2018 growing season. The lowest amount of $\mathrm{N}$ absorbed by corn reduced its content in the tissues and, consequently, influenced the SPAD index at R1, when $\mathrm{N}$ was not topdressed applied. This fact was also observed by Neto-Neto et al. (2013), who found that the increased density of ruzigrass increased the interspecific competition for $\mathrm{N}$ and reduced the corn SPAD index.

Souza et al. (2019) tested different cornrattlebox intercropping systems and found that systems in which rattlebox was sown in the inter-rows and at the same time as corn had a SPAD index that showed no difference from corn monocropping, as observed in the present study (Figure 2A). The low competition capacity of showy rattlebox with corn is an important characteristic to be considered for its use in the intercropped cultivation system, during the second crop cultivation.

The NDVI at V4 and V7 in corn intercropped with ruzigrass was higher than for corn monocropping in both growing seasons (Figures $2 \mathrm{~B}$ and $2 \mathrm{C}$ ). NDVI is used to monitor the amount of plant biomass from the shoots of a crop (Padilla et al. 2018). It indicates that the intercropping with ruzigrass promoted a higher vegetation cover at the beginning of the corn cycle, reducing water erosion and weed infestation.

The methodology for estimating the productive potential of corn as a function of NDVI developed by Vian et al. (2018) showed NDVI values at V4 of 0.550.59 in the 2018 growing season, characterizing a high yield (NDVI $\geq 0.47$ ). It occurred probably because the water availability conditions up to V4 were favorable, unlike the later phenological stages (Figures $2 \mathrm{~B}$ and $2 \mathrm{C})$. In the 2019 growing season, the values observed at V7 indicated a low yield (NDVI $<0.52$ ).

In the 2018 growing season, the leaf area of corn intercropped with ruzigrass was smaller than for corn intercropped with showy rattlebox in the absence of topdressing $\mathrm{N}$ fertilization (Figure 3A). In the 2019 growing season, the leaf area of corn intercropped with ruzigrass was lower than for monocropping in the absence of topdressing $\mathrm{N}$ fertilization (Figure 3B). The high competition capacity of ruzigrass for environmental resources in the intercropping system reduced by $25 \%$ the leaf area per corn plant, when compared to the corn-showy rattlebox intercropping in the 2018 
growing season, and by $12 \%$, if compared to corn monocropping in the 2019 growing season. Therefore, the year with better weather conditions reduced the competition between grain and forage crops.

Silva et al. (2013) observed that 20 plants $\mathrm{m}^{-2}$ of ruzigrass sown simultaneously with corn presented a $10 \%$ reduction in its leaf area, when compared to corn monocropping. In this case, the competition between corn and ruzigrass for water, light and nutrients contributed to reducing the leaf area, as observed in the present study.

The leaf area of the corn monocropping and that intercropped showed no difference from each other in both growing seasons, when $\mathrm{N}$ was used (Figures 3A and 3B). According to Makino et al. (2019), the reduction in the leaf area of corn intercropped with ruzigrass, when compared to monocropping, is due to a decrease in the nutrient content available in the soil of the intercropped system, especially N. In this sense, the increased N rates in the 2019 growing season linearly increased the leaf area of the corn intercropped with ruzigrass (Figure 3B), what, however, was not observed in the previous growing season (Figure $3 \mathrm{~A}$ ). The three cultivation systems evaluated in the 2018 growing season had no increase in the leaf area with the increase in $\mathrm{N}$ rates, the same being observed for corn monocropping and intercropped with ruzigrass in the 2019 growing season (Figures 3A and 3B). This shows that the environmental conditions of secondcrop corn in the northern Paraná state, especially water deficit, limits its responses to $\mathrm{N}$.

The experimental factors in the 2018 growing season showed no interference in the response of corn total dry mass at R6. In the 2019 growing season, the total dry mass of corn intercropped with ruzigrass was

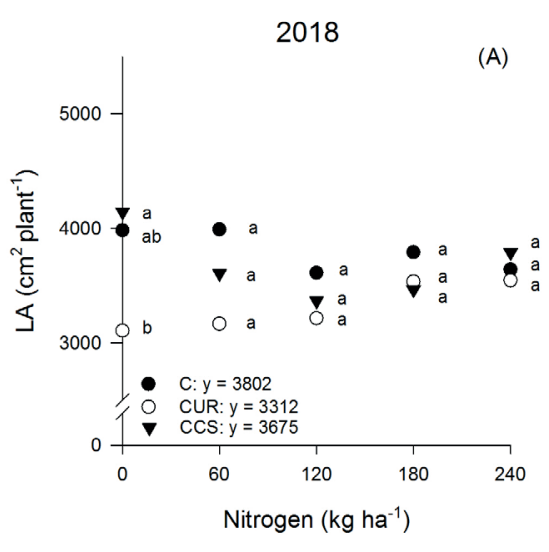

2019

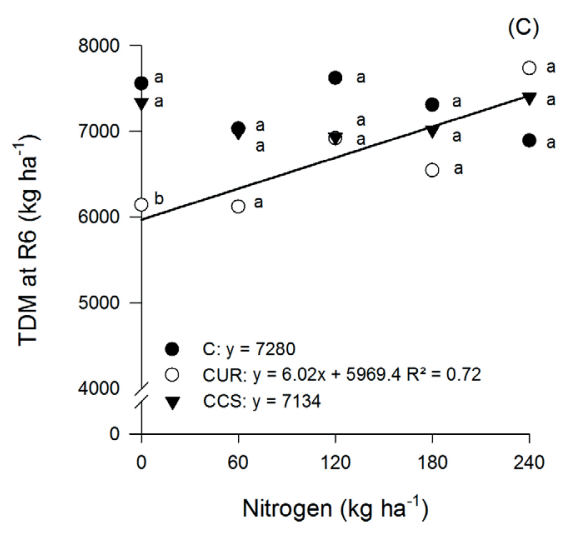

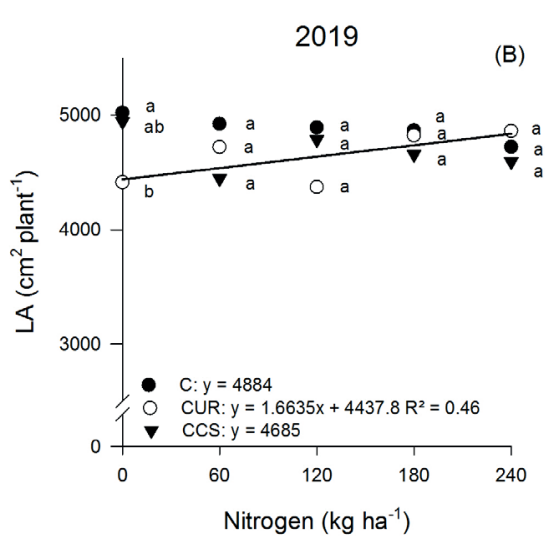

2019

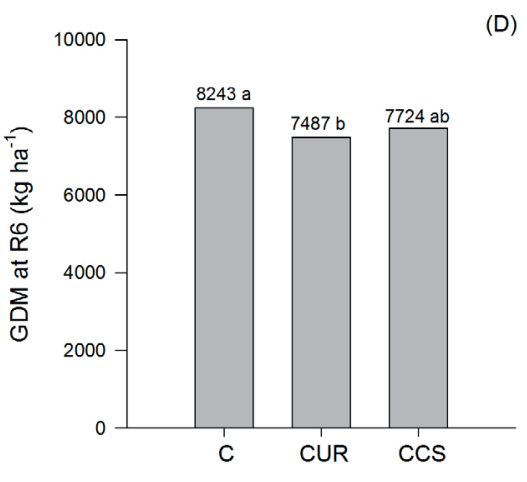

Figure 3. Effect of cultivation systems (C: corn monocropping; CUR: corn + Urochloa ruziziensis; and CCS: corn + Crotalaria spectabilis $)$ and topdressing nitrogen rates $\left(0,60,120,180\right.$ and $\left.240 \mathrm{~kg} \mathrm{ha}^{-1}\right)$ on second-crop corn, regarding the leaf area at R1 (LA) (A and B), total dry mass of corn (TDM) at R6 and grain dry mass (GDM) at R6 (C and D), during the secondcrop cultivation of 2018 and 2019. Means followed by the same letter within each nitrogen rate do not differ from each other by the Tukey test at $5 \%$ of probability. 
lower than for monocropping and intercropping with showy rattlebox by 18 and $16 \%$, respectively, in the absence of topdressing $\mathrm{N}$ fertilization (Figure 3C). However, this difference was not observed with the application of the lowest topdressing $\mathrm{N}$ rate $\left(60 \mathrm{~kg} \mathrm{ha}^{-1}\right)$. The topdressing $\mathrm{N}$ fertilization in corn reduced the interspecific competition in the intercropping with ruzigrass, indicating the need for supplementation with $\mathrm{N}$ fertilization, as the $\mathrm{N}$ used for sowing $\left(34 \mathrm{~kg} \mathrm{ha}^{-1}\right)$ and that from the decomposition of plant residues and soil were not sufficient to supply the $\mathrm{N}$ demand.

The obtained results corroborate Almeida et al. (2017), who observed that corn intercropped with $U$. ruziziensis without $\mathrm{N}$ fertilization produced $17 \%$ less dry mass than the monocropping, but the dry mass did not differ between the systems at rates higher than $100 \mathrm{~kg} \mathrm{ha}^{-1}$ of $\mathrm{N}$. These results show the importance of $\mathrm{N}$ fertilization in the cultivation of corn intercropped with ruzigrass.

The 2019 growing season showed a linear increase in the total dry mass with the increase of $\mathrm{N}$ rates applied to the corn-ruzigrass intercropping, a behavior not observed for monocropping and corn intercropped with showy rattlebox. Lange et al. (2014) also found a linear response of dry mass to $\mathrm{N}$ rates in corn intercropped with $U$. brizantha, showing the relevance of using topdressing $\mathrm{N}$ fertilization to accumulate mass in intercropped corn.

The grain dry mass at R6, in the 2018 growing season, was not influenced by the experimental factors. In the 2019 growing season, it was higher in the corn monocropping than in corn intercropped with ruzigrass (Figure 3D), showing its competition with corn. Silva et al. (2013) observed that an increase in the density of ruzigrass intercropped with corn reduced the leaf dry mass and, consequently, decreased the photosynthetic capacity of plants, causing a decrease in grain dry mass.

The number of ears per plant for corn monocropping in the absence of topdressing $\mathrm{N}$ fertilization was higher than that for corn intercropped with ruzigrass, in the 2018 growing season, what was not observed with the topdressing $\mathrm{N}$ application (Figure 4A). Topdressing $\mathrm{N}$ fertilization can reduce the competition for $\mathrm{N}$ between corn and ruzigrass under a water deficit situation from V4 (Figure 1), allowing the formation of the same value for number of ears per plant in both systems. The intercropping of corn with ruzigrass did not change the number of ears per plant in the 2019 growing season, in which there was also no water deficit until V4 (Figure 1), even in the absence of topdressing $\mathrm{N}$ fertilization.

The number of grains per ear was not influenced by the experimental factors in the 2018 growing season. In the 2019 growing season, the number of grains per ear of corn intercropped with ruzigrass was lower than for monocropping, when $\mathrm{N}$ was not topdressed applied and at a rate of $60 \mathrm{~kg} \mathrm{ha}^{-1}$ (Figure 4B). This result agrees with Ceccon et al. (2014), who found that corn monocropping produced a higher number of grains per ear than for intercropping with ruzigrass. In turn, the intercropping system with showy rattlebox did not change the number of grains per ear, if compared to monocropping, at all $\mathrm{N}$ rates, showing a lower competitiveness of the showy rattlebox, when compared to ruzigrass.

The experimental factors in the 2018 growing season showed no influence on the 1,000-grain mass. In the 2019 growing season, the 1,000-grain mass of corn intercropped with showy rattlebox was higher than that for intercropping with ruzigrass with no topdressing $\mathrm{N}$ fertilization, but this difference was not observed when this nutrient was applied (Figure 4C). However, the intercropped corn did not differ from monocropping for this characteristic. Gerlach et al. (2019) tested corn intercropping with different leguminous species sown simultaneously under no-tillage and found no differences between corn monocropping and intercropped with C. spectabilis, regarding the 1,000-grain mass.

Similarly, Borghi et al. (2012) observed no differences between corn monocropping and intercropped with ruzigrass sown simultaneously, regarding the 1,000-grain mass. Thus, the difference in 1,000-grain mass observed in the present study was restricted to the absence of $\mathrm{N}$ topdressed applied and may be explained by the higher competition imposed by ruzigrass, when compared to showy rattlebox.

In the 2019 growing season, the 1,000-grain mass presented a quadratic adjustment to $\mathrm{N}$ rates for corn monocropping and intercropped with ruzigrass (Figure $4 \mathrm{C}$ ). The maximum point in the corn monocropping was for $170 \mathrm{~kg} \mathrm{ha}^{-1}$ of $\mathrm{N}$, with 1,000-grain mass of $324 \mathrm{~g}$, and $169 \mathrm{~kg} \mathrm{ha}^{-1}$ of $\mathrm{N}$ for corn intercropped with ruzigrass, with a value of $321 \mathrm{~g}$. Similarly, Goes et al. (2013) found that the 1,000-grain mass of corn intercropped with ruzigrass showed a quadratic response to the 
2018

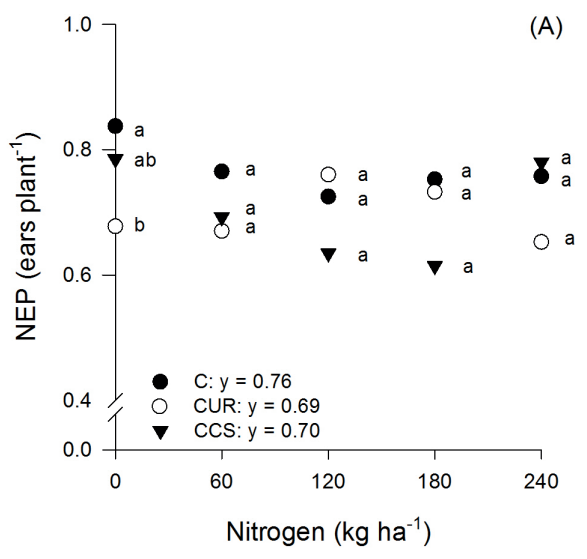

2019

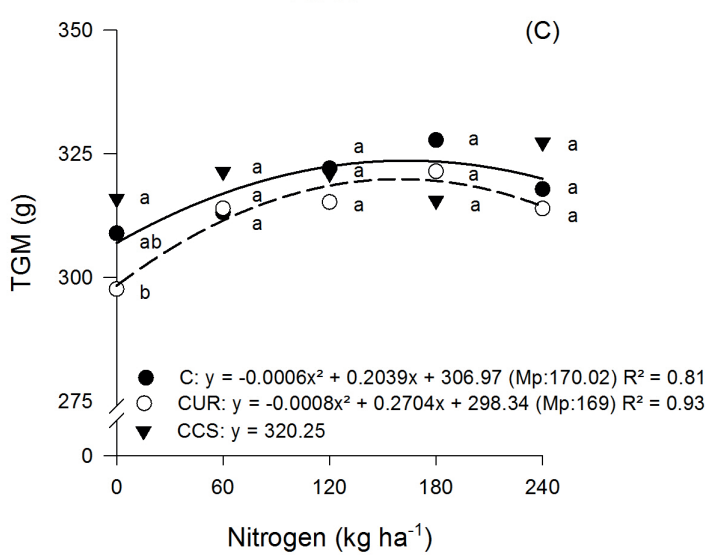

2019

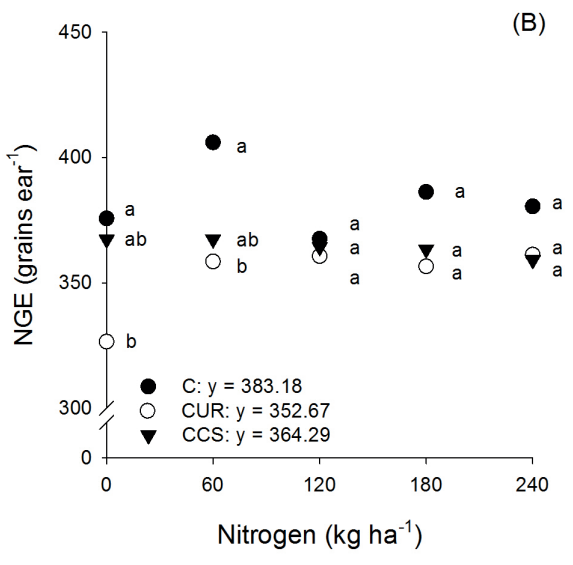

2019

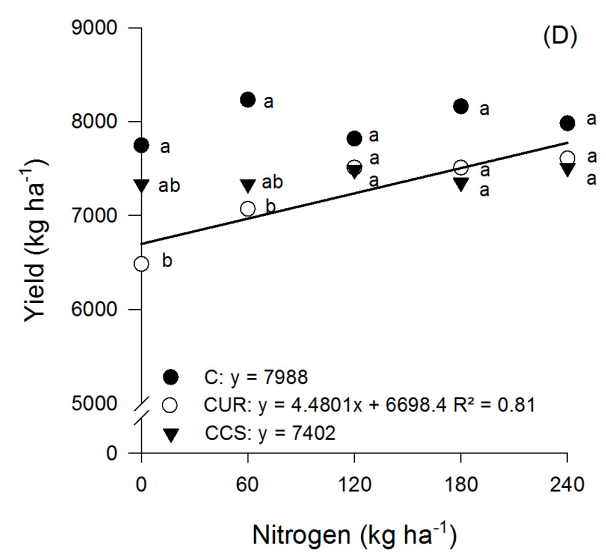

Figure 4. Effect of cultivation systems (C: corn monocropping; CUR: corn + Urochloa ruziziensis; and CCS: corn + Crotalaria spectabilis $)$ and topdressing nitrogen rates $\left(0,60,120,180\right.$ and $\left.240 \mathrm{~kg} \mathrm{ha}^{-1}\right)$ on second-crop corn, regarding the number of ears per plant (NEP) (A), number of grains per ear (NGE) (B), 1,000-grain mass (TGM) (C) and grain yield (D), during the second crop cultivation of 2018 and 2019. Means followed by the same letter within each nitrogen rate do not differ from each other by the Tukey test at $5 \%$ of probability. Mp: maximum point.

increase in topdressing $\mathrm{N}$ rates $(0,40,80,120$ and $\left.160 \mathrm{~kg} \mathrm{ha}^{-1}\right)$, with the highest value (206 g) obtained with $110 \mathrm{~kg} \mathrm{ha}^{-1}$ of $\mathrm{N}$.

The 2018 growing season showed no effect of the experimental factors on grain yield. That probably occurred because the water restriction was intense after V4 until the physiological maturation. In 2019, the corn intercropped with ruzigrass showed a lower yield than that observed for corn monocropping up to $60 \mathrm{~kg} \mathrm{ha}^{-1}$ of N (Figure 4D). The corn yield with no topdressing $\mathrm{N}$ fertilization in the intercropping with ruzigrass was $16 \%$ lower than for monocropping. No difference in corn yield was observed between corn intercropped with ruzigrass $\left(7,485 \mathrm{~kg} \mathrm{ha}^{-1}\right)$ and monocropping $\left(7,817 \mathrm{~kg} \mathrm{ha}^{-1}\right)$ from the topdressing $\mathrm{N}$ rate of $120 \mathrm{~kg} \mathrm{ha}^{-1}$. This result corroborates Almeida et al. (2017), who observed that the grain yield was reduced by the intercropping with ruzigrass at $\mathrm{N}$ rates below $100 \mathrm{~kg} \mathrm{ha}^{-1}$. Grain formation is highly related to the translocation of assimilates and $\mathrm{N}$ into vegetative organs (Batista et al. 2019a), so that the increased $\mathrm{N}$ supply reduced the negative effect of the competition with ruzigrass.

The corn yield in the intercropping with ruzigrass increased $4.48 \mathrm{~kg} \mathrm{ha}^{-1}$ of grains for each $\mathrm{kg}$ of $\mathrm{N}$ topdressed applied (Figure 4D). This result shows the need of $\mathrm{N}$ fertilization in the secondcrop corn intercropped with ruzigrass. Batista et al. (2019b) found that second-crop corn intercropped with ruzigrass requires $\mathrm{N}$ fertilization management to complement the amount of $\mathrm{N}$ provided by the soil, to minimize the competition for this nutrient. 
In general, the corn intercropped with C. spectabilis did not have its growth and yield compromised by the leguminous species, regardless of the $\mathrm{N}$ rate. Therefore, the use of corn-showy rattlebox intercropping may be an important alternative in regions with no water deficit and low temperatures in the second crop cultivation, as the C. spectabilis sowed in inter-rows presents a low competition with corn, not reducing the corn yield nor harming the harvesting operations, as observed by Souza et al. (2019). Moreover, a pivoting root system and biomass production with a low $\mathrm{C} / \mathrm{N}$ ratio are important attributes to consider the inclusion of the legume in the no-tillage system, aiming at diversifying it, promoting an increase in the organic matter content, improving the soil structure and increasing the $\mathrm{N}$ availability (Gitti et al. 2012).

According to Simão et al. (2018), the sowing season defines the water availability conditions and influences the second-crop corn yield, so that the earlier sowing favors its yield. Corn was sown on March 16 in the 2018 growing season and March 6 in the 2019 growing season. It is possible that the early sowing in both growing seasons might reduce the negative effects of the water deficit on corn growth, development and yield.

\section{CONCLUSIONS}

1. The absence of nitrogen $(\mathrm{N})$ fertilization and the topdressed use of $60 \mathrm{~kg} \mathrm{ha}^{-1}$ of $\mathrm{N}$ showed that the intercropping with $U$. ruziziensis reduces the growth and productive performance of secondcrop corn;

2. The topdressing $\mathrm{N}$ fertilization in second-crop corn intercropped with $U$. ruziziensis minimizes the forage competition in corn growth and provides a productive performance similar to that of the corn monocropping from the rate of $120 \mathrm{~kg} \mathrm{ha}^{-1}$ of N;

3. The intercropping with $C$. spectabilis does not change the corn growth and its productive performance, as well as the response to the topdressed $\mathrm{N}$ rates, when compared to corn monocropping in the second-crop cultivation.

\section{ACKNOWLEDGMENTS}

This study was carried out with the support of the Coordenação de Aperfeiçoamento de Pessoal de Nível Superior (Capes - Brazil - Financing code 001).

\section{REFERENCES}

ALMEIDA, R. E. M.; FAVARIN, J. L.; OTTO, R.; PIEROZAN, C.; OLIVEIRA, S. M.; TEZOTTO, T.; LAGO, B. C. Effects of nitrogen fertilization on yield components in a corn-palisadegrass intercropping system. Australian Journal of Crop Science, v. 11, n. 3, p. 352359, 2017.

AL-NAGGAR, A. M. M.; SHABANA, R. A.; ATTA, M. M.; AL-KHALIL, T. H. Maize response to elevated plant density combined with lowered $\mathrm{N}$-fertilizer rate is genotype-dependent. The Crop Journal, v. 3, n. 2, p. 96109, 2015.

BALBINOT JUNIOR, A. A.; SANTOS, J. C. F. D.; DEBIASI, H.; YOKOYAMA, A. H. Contribution of roots and shoots of brachiaria species to soybean performance in succession. Pesquisa Agropecuária Brasileira, v. 52, n. 8, p. 592-598, 2017.

BATISTA, K.; GIACOMINI, A. A.; GERDES, L.; MATTOS, W. T. de; OTSUK, I. P. Nitrogen fertilisation improves the grain production efficiency and sustainability of out-of-season corn and congo grass intercropping. Soil Research, v. 57, n. 4, p. 397-407, 2019 b.

BATISTA, V. V.; GIARETTA, R.; LINK, L.; GIACOMEL, C. L.; ADAMI, P. F. Densidades de plantas e níveis de nitrogênio no desempenho de híbridos de milho em safrinha. Revista Nativa, v. 7, n. 2, p. 117-125, 2019a.

BORGHI, É.; CRUSCIOL, C. A. C.; NASCENTE, A. S.; MATEUS, G. P.; MARTINS, P. O.; COSTA, C. Effects of row spacing and intercrop on maize grain yield and forage production of palisade grass. Crop and Pasture Science, v. 63, n. 12 , p. 1106-1113, 2012.

CECCON, G.; SILVA, J. F. da; NETO, A. L. N.; MAKINO, P. A.; SANTOS, A. dos. Produtividade de milho safrinha em espaçamento reduzido com populações de milho e de brachiaria. Revista Brasileira de Milho e Sorgo, v. 13, n. 3, p. 326-335, 2014.

CHIODEROLI, C. A.; MELLO, L. M. de; GRIGOLLI, P. J.; FURLANI, C. E.; SILVA, J. O.; CESARIN, A. L. Atributos físicos do solo e produtividade de soja em sistema de consórcio milho e braquiária. Revista Brasileira de Engenharia Agrícola e Ambiental, v. 16, n. 1, p. 37 43, 2012.

COMPANHIA NACIONAL DE ABASTECIMENTO (Conab). Acompanhamento da safra brasileira de grãos. 2020. Disponível em: www.conab.gov.br/info-agro/safras/ graos/boletim-da-safra-de-graos. Acesso em: 10 jan. 2020.

CRUZ, J. C.; FILHO PEREIRA, I. A.; ALVARENGA, R. C. Ecofisiologia, fenologia e implicações básicas de manejo. In: GALVÃO, J. C. C.; BORÉM, A.; PIMENTEL, 
M. A. Milho: do plantio à colheita. Viçosa: Ed. UFV, 2017. p. $50-76$.

FERREIRA, D. F. Sisvar: a computer statistical analysis system. Ciência e Agrotecnologia, v. 35, n. 6, p. 10391042, 2011.

FRANCHINI, J. C.; BALBINOT JUNIOR, A. A.; DEBIASI, H.; CONTE, O. Soybean performance as affected by desiccation time of Urochloa ruziziensis and grazing pressures. Revista Ciência Agronômica, v. 45, n. 5 , p. 999-1005, 2014.

GERLACH, G. A. X.; SILVA, J. C.; ARF, O. Resposta do milho em consórcio com adubos verdes no sistema plantio direto. Acta Iguazu, v. 8, n. 2, p. 134-146, 2019.

GITTI, D. C.; ARF, O.; VILELA, R. G.; PORTUGAL, J. R.; KANEKO, F. H.; RODRIGUES, R. A. F. Épocas de semeadura de crotalária em consórcio com milho. Revista Brasileira de Milho e Sorgo, v. 11, n. 2, p. 156-158, 2012.

GOES, R. J.; RODRIGUES, R. A. F.; TAKASU, A. T.; ARF, O. Características agronômicas e produtividade do milho sob fontes e doses de nitrogênio em cobertura no inverno. Revista Brasileira de Milho e Sorgo, v. 12, n. 3, p. 250-259, 2013.

KAPPES, C.; CARVALHO, M. A. C. de; YAMASHITA, O. M.; SILVA, J. A. N. da. Influência do nitrogênio no desempenho produtivo do milho cultivado na segunda safra em sucessão à soja. Pesquisa Agropecuária Tropical, v. 39, n. 3, p. 251-259, 2009.

KAPPES, C.; ZANCANARO, L. Sistemas de consórcios de braquiária e de crotalárias com a cultura do milho. Revista Brasileira de Milho e Sorgo, v. 14, n. 2, p. 219234, 2015.

LANGE, A.; CAIONE, G.; SCHONINGER, E. L.; SILVA, R. G. Produtividade de milho safrinha em consórcio com capim-marandu em função de fontes e doses de nitrogênio em cobertura. Revista Brasileira de Milho e Sorgo, v. 13, n. 1, p. 35-47, 2014.

MAHAMA, G. Y.; VARA PRASAD, P. V.; ROOZEBOOM, K. L.; NIPPERT, J. B.; RICE, C. W. Response of maize to cover crops, fertilizer nitrogen rates, and economic return. Agronomy Journal, v. 108, n. 1, p. 17-31, 2016.

MAKINO, P. A.; CECCON, G.; FACHINELLI, R. Produtividade e teor de nutrientes em populações de milho safrinha solteiro e consorciado com braquiária. Revista Brasileira de Milho e Sorgo, v. 18, n. 2, p. 206-220, 2019.

MALDANER, L. J.; HORING, K.; SCHNEIDER, J. F.; FRIGO, J. P.; AZEVEDO, K. D.; GRZESIUCK, A. E. Exigência agroclimática da cultura do milho. Revista Brasileira de Energias Renováveis, v. 3, n. 1, p. 13-23, 2014.
NETO-NETO, A. L.; SILVA, J. F. da; SANTOS, A. dos; PADILHA, N. D. S.; MAKINO, P. A.; CECCON, G. Morphophysiology and yield of late season maize intercropped with urochloa in reduced row spacing. Revista Brasileira de Milho e Sorgo, v. 12, n. 3, p. $227-$ 239, 2013.

PADILLA, F. M.; GALLARDO, M.; PEÑA-FLEITAS, M. T.; SOUZA, R. de; THOMPSON, R. B. Proximal optical sensors for nitrogen management of vegetable crops: a review. Sensors, v. 18, n. 7, p. 2083-2105, 2018.

PERECIN, D.; CARGNELUTTI FILHO, A. Efeitos por comparações e por experimento em interações de experimentos fatoriais. Ciência e Agrotecnologia, v. 32, n. 1, p. 68-72, 2008.

RAASCH, H.; SCHONINGER, E. L.; NOETZOLD, R.; VAZ, D. da C.; SILVA, J. D. da. Doses de nitrogênio em cobertura no milho de segunda safra em Nova Mutum MT. Revista Cultivando o Saber, v. 4, n. 4, p. 517-529, 2016.

SANTOS, H. G.; JACOMINE, P. K. T.; ANJOS, L. H. C.; OLIVEIRA, V. A.; LUMBRERAS, J. F.; COELHO, M. R.; ALMEIDA, J. A.; ARAUJO FILHO, J. C.; OLIVEIRA, J. B.; CUNHA, T. J. F. Sistema brasileiro de classificação de solos. 5. ed. Brasília, DF: Embrapa, 2018.

SIBALDELLI, R. N. R.; FARIAS, J. R. B. Boletim agrometeorológico da Embrapa Soja Londrina, PR-2014. Londrina: Embrapa Soja, 2018. (Documento, 399).

SILVA, J. F.; NETO, N.; SANTOS, A. D.; CECCON, G. Morphophysiology of late season maize at reduced spacing and intercropped with Urochloa ruziziensis. Revista Agrarian, v. 6, n. 21, p. 259-267, 2013.

SIMÃO, E. D. P.; RESENDE, A. V.; GONTIJO NETO, M. M.; BORGHI, E.; VANIN, A. Resposta do milho safrinha à adubação em duas épocas de semeadura. Revista Brasileira de Milho e Sorgo, v. 17, n. 1, p. 76-90, 2018.

SOUZA, R. T. de; VALADÃO, F. C. de A.; VALADÃO JÚNIOR, D. D.; GUIMARÃES, P. R.; PAULA, V. R. R. de. Maize-crotalaria intercropping systems. Revista Semina, v. 40, n. 4, p. 1455-1468, 2019.

THORNTHWAITE, C. W.; MATHER, J. R. The water balance. Centerton: Drexel Institute of Technology, 1955.

UNITED STATES DEPARTMENTOFAGRICULTURE (USDA). Soil Survey Staff. Keys to soil taxonomy. 12. ed. Washington, D.C.: USDA, 2014.

VIAN, A. L.; BREDEMEIER, C.; SILVA, P. R. F. da; SANTI, A. L.; GIORDANO, C. P. D. S. Limites críticos de NDVI para estimativa do potencial produtivo do milho. Revista Brasileira de Milho e Sorgo, v. 17, n. 1, p. 91-100, 2018. 